\title{
No-fault divorce in Canada: Its cause and effect
}

\author{
Douglas W. Allen \\ Department of Economics, Simon Fraser University, Burnaby, BC, Canada, V5A 1S6
}

Received 10 June 1996; accepted 8 January 1997

\begin{abstract}
The rise of no-fault divorce laws throughout the western world in the early 1970s is argued to be the result of a rise in the number of inefficient marriages during the 1940s-1960s. These marriages resulted in part from changes in the work force patterns of women that were unanticipated by men. The hypothesis is tested with Canadian data. In addition to this, further evidence is brought to bear on the effect of no-fault divorce on the divorce rate. (C) 1998 Elsevier Science B.V. All rights reserved.
\end{abstract}

\section{Introduction}

The United States and Canada introduced no-fault divorce laws in the late 1960s, and it is now common in many western countries. ${ }^{1}$ To date much of the academic debate over the law has centered on what its effect has been on the divorce rate in the United States. The result of this debate is still inconclusive, partly because creating a clean U.S. test is so difficult, but also because differences in other features of divorce law have often been ignored - particularly differences in rules for allocating property at divorce. What has yet to be seriously considered by economists, however, is why such a law became so popular in the first place. Jacob (1988) has called the change in divorce law the 'silent revolution,'

\footnotetext{
${ }^{1}$ Most European countries reformed during the early 1970s. For example, England became no-fault in 1969, the Netherlands in 1971, Sweden in 1973, and France in 1975. On the other side of the world, Australia introduced no-fault divorce in 1974. Not only is no-fault divorce common, but it appears to have been adopted practically simultaneously. No-fault divorce generally eliminates all traditional grounds for divorce or adds some notion of 'incompatibility' to existing grounds. The economic consequence of no-fault divorce is to create a unilateral law where either partner can terminate the marriage without the other spouse's consent. Fault divorce law, though not the same as a mutual consent law, often amounts to as much since collusion and agreement between the parties was often required to reach a divorce. According to Freed and Foster (1979):
}

Under the traditional nineteenth and early twentieth century grounds for divorce, over 90 percent of divorces were uncontested and hence there was divorce by mutual agreement. (p.107) 
and holds that no-fault divorce virtually came about by accident, or at least as an unconsidered consequence of efforts to make the divorce process more honest and open. Posner (1992, p. 252) provides a similar explanation, stating that "confining divorce to grounds... [leads to investing]... resources in manufacturing them. ... At this point internal goals of the legal system - the goals of economizing on judicial resources and of reducing perjury - become decisive in favor of allowing either consensual divorce or divorce at will."

As a historical fact, efforts to reduce judicial resources and perjury may well have been the grounds by which some countries arrived at no-fault divorce law. However, this cannot explain why no-fault divorce laws have survived. If it were the case, as many have claimed (see, e.g. Parkman, 1992a), that no-fault divorce imposed unexpected costs on third parties (e.g. spouses and children) that were greater than any benefits, then it would not matter if that law was arrived at willy-nilly, as a matter of patch-work routine, as a method of reducing perjury, or as the result of local special interests. Efficiency within the legal process would lead to such a law being revoked, not enforced or modified, and certainly not adopted by other jurisdictions.

Yet no-fault divorce is common place. Indeed, even the character of the law remains unchanged: the 1985 no-fault divorce law of South Dakota is in the same spirit as the 1970 law of California; the U.S. law is similar in spirit to the law in Canada. In those U.S. states where marital property was divided based on legal title, and where most of the nonvoluntary wealth transfers from wives to husbands took place after the introduction of nofault divorce due to the tendency of husbands holding legal title, the law was not repealed. ${ }^{2}$ Rather, changes were made in the other areas of the divorce law, most notably property division, and the no-fault process was retained. Hence, despite the silent or accidental appearance given the acquisition of these laws, their rapid spread and resistance to repeal suggests, or at least is consistent with, their being efficient. ${ }^{3}$

In this paper I argue that no-fault divorce laws were motivated by efficiency. In particular, I argue that due to social changes after the second World War, there were increases in the number of inefficient marriages, ${ }^{4}$ and that the change in the divorce law reduced the cost of being married by making it easier to escape a past mistake. Unfortunately, no law is perfect, and the elimination of fault grounds for divorce solved some problems, but created others. Just as there are inefficient marriages under fault law, there are also inefficient divorces under no-fault law. ${ }^{5}$ In both cases, transaction costs

\footnotetext{
${ }^{2}$ In the US there have been several court challenges on the ground that no-fault deprived women of some type of property right. However, these have all been unsuccessful. For example, In re Walton's Marriage, $28 \mathrm{Cal}$. App. 3d 108, 104 Cal. Rptr. 472 (1972), considers this issue. I am grateful to Margaret Brinig for pointing this out. See Allen (1990) for a detailed explanation of how the wealth transfers took place and empirical evidence to support it.

${ }^{3}$ Some may argue that this fact speaks more to entrenched interests and ratchet effects in legislation. There is a growing literature which argues that governments are capable of reaching efficient outcomes (e.g. see Wittman, 1989). Ultimately the answer over which view can better explain actual practices is an empirical one.

${ }^{4}$ By this I mean a marriage where total wealth is higher when the couple is separated than when together. Of course, wealth here refers to the dollar equivalent of the present value of the stream of utility generated by marriage. As such it reflects anything that individuals value in the marriage. It is not a myopic measure of mere cash flows.

${ }^{5}$ An inefficient divorce is the opposite of an inefficient marriage. Total wealth is higher when the couple is together than when they are separated.
} 
arise as some spouses exploit the laws to their favor. The hypothesis here is that the law was, and continues to be, chosen to maximize the gains from trade net of transaction costs. $^{6}$

Aside from providing a theoretical explanation for the change in divorce laws, an effort is made to test the hypothesis using a detailed analysis of the Canadian experience with no-fault divorce. Unlike other empirical approaches to this question, an attempt is made to segregate the effect of no-fault divorce on efficient and inefficient divorces. Hence, in the process of explaining the emergence of this law, further evidence on its effect is provided as well.

For several reasons, this second aspect of the paper is an important contribution to the debate on the effect of no-fault divorce. First, to date, the no-fault divorce debate has taken place almost entirely in an American context, and the time has come for broader testing. Second, unlike the US, the Canada Divorce Act is a federal law. As a result, there is a clear change in the law and problems of legal definition are avoided. In the divorce literature there is still disagreement over the classification of several state laws, and the cross-sectional results on the effect of no-fault laws on the divorce rate turn out to be very sensitive to state classifications. ${ }^{7}$ Finally, demonstrating that no-fault divorce did raise the divorce rate in Canada highlights the puzzle of the initial question of this paper, namely, why would a law be introduced and maintained that increased the incidence of divorce?

The paper is organized as follows. Section 2 provides a brief discussion on the notion of efficient and inefficient marriages, and introduces the metaphor 'marriage as a contract,' which may not be familiar to all readers. Section 3 then briefly discusses economic theories of divorce in order to direct the inquiry as to what would cause a large rise in the number of inefficient marriages that would motivate demand for legal reform. This section settles on changes in the level and type of female labor force participation as the main driving factor. Finally, Section 4 tests the hypothesis over the cause of no-fault divorce, and provides estimates of its effect as well.

\section{Efficient and inefficient marriages}

In a world of zero transaction costs there would never be any inefficient marriages or divorces. If wealth is higher when a couple is together rather than apart they always remain married - regardless of the divorce law. ${ }^{8}$ Although the jury is still out, evidence is mounting, and more is presented in this paper, which suggests that the switch to no-fault

\footnotetext{
${ }^{6}$ Transaction costs are defined as the costs of establishing and maintaining property rights. This definition is elaborated on in Allen (1991). Examples of how it pertains to marriage are contained later in the paper, as well as Allen (1990, 1992b).

${ }^{7}$ For example, many states have always allowed 'separation' as a ground for divorce. Some have argued these states are, for economic purposes, no-fault states, while others maintain they are fault states. See Allen (1992b) for a discussion of the sensitivity issue.

${ }^{8}$ Becker et al. (1977) were the first to note this application of the Coase theorem; Peters (1986) elaborates on it in considerable detail.
} 
divorce increased the divorce rate, ${ }^{9}$ and in some instances the impact was substantial. ${ }^{10}$ The divorce rate neutrality across legal regimes breaks down because transaction costs, in one form or another, prevent the spouse least wanting a divorce from compensating the instigator of the divorce. But what has generally gone unnoticed in the context of the divorce literature is that the problem of nonneutrality is reciprocal. ${ }^{11}$ Under no-fault divorce some marriages break up when they should not (the case always looked at), but under fault divorce some marriages remain together when, in principle, the parties would be better off splitting up.

The number and types of transaction costs that may result in inefficient divorces under no-fault divorce laws would seem to be quite large. First, quirks in property laws at the time of divorce can easily create situations whereby efficient marriages dissolve. ${ }^{12}$ Second, government failures to enforce support payments for children and spouse allow the instigating party to avoid some of the costs of (usually) his actions. Hence the private values of the party leaving the marriage can be out of line with the joint value of the marriage. Third, many family assets (including children) may be indivisible, making them difficult and costly to bargain over at the time of divorce. Finally, violent reactions by a spouse may make renegotiating the terms of the marriage too costly, and an inefficient divorce may occur. In fact, the idea that no-fault divorce allows for inefficient outcomes is quite common. Parkman (1992b) devotes a whole paper on this point, and starts off by stating: "This article argues that the current divorce laws tend to produce inefficient outcomes." (p. 3)

What is not commonly recognized is that under fault law there were inefficient marriages; that is, the reciprocal nature of the problem is often ignored. ${ }^{13}$ The reason is that similar transaction cost problems hold true for inefficient marriages under fault divorce. For example, suppose a couple marries, neither of their expectations are met and, although one partner wishes to remain married, total wealth is higher if they separate. If the husband wants the divorce, the wife may not agree if she believes the husband will default on alimony and the state will not enforce the divorce agreement. In other words, the potential transaction costs of privately enforcing a separation agreement may prevent the agreement in the first place. Transaction costs may also arise over non-transferable wealth, from indivisibilities in marital property or children, or from violence or threats of violence, that again may prevent a bargain from taking place.

\footnotetext{
${ }^{9}$ For discussions on past research see Marvell (1989) and Zelder (1992), both of whom conclude that the law increased the divorce rate. For a more specific example of the debate see Allen (1992b) and Peters (1992).

${ }^{10}$ See, for example, Allen (1990).

${ }^{11}$ I use the term reciprocal in the same sense that Coase (1960) used it. It does not mean symmetric.

12 Allen (1990) examines the effect of 'title' property laws on the post-divorce wealth of divorced women. Another example is 'the medical school syndrome' where courts failed to classify degrees and certificates as property, and therefore, not subject to division. In fact, courts are continually being asked to make decisions on what is classed as marital property, from pensions, to lost human capital due to child birth.

${ }^{13}$ Peters (1986), however, mentions in passing that under mutual (fault) law some divorces should occur but do not.
} 
Hence the presence of transaction costs implies some inefficient marriages when there is fault divorce and some inefficient divorces under no-fault divorce. An efficient law is chosen such that the larger of the two problems is avoided. ${ }^{14}$ When situations arise that make inefficient marriages rare, then fault law is expected to arise. The advantage of a fault law is that divorce generally requires mutual consent. This releases the state from defining and adjudicating most property disputes and spousal support, since a property settlement is usually reached by the parties themselves prior to the divorce and without the state's input. ${ }^{15}$ As the probability of inefficient marriages increases, the cost of a fault divorce law increases. At some point society benefits from the introduction of a no-fault law. ${ }^{16}$

The first issue dealt with in this paper is to enquire what could have happened over the 1950 s and 1960s to induce a large number of inefficient marriages and hence create a demand for legal reform? At first glance there appear to be many factors that could have caused an increase in the number of inefficient marriages during this time. Michael (1978) has noted that the introduction of oral contraceptives reduced the number of children per couple which could destabilize marriages. Fuchs (1983) argues that changes in real earnings, contraception, feminist ideology, and widespread criticism of traditional institutions and norms during the late 1960s and 1970s may also have spurred the demand for no-fault reform. In this paper I focus on labor force participation by women as the central cause in the increase for divorce reform. This is done, not at the expense of these other factors, but because it is believed that the truly destabilizing effects of oral contraceptives, feminist ideology, and the rest are how they manifest in work behavior.

\section{Economic rationales for divorce}

In their seminal article on marital dissolutions Becker et al. (1977) argue that the probability of divorce depends on the expected gain from marriage and the variability of outcomes during marriage. Labor force participation on the part of women tends to increase the probability of divorce because it lowers the gains from marriage that are achieved by one spouse specializing in household production. Further, when the gains from marriage are low, both parties tend to reduce specific investments in the marriage which further lowers the cost of divorce. Larger variances in marital outcomes increase

\footnotetext{
${ }^{14}$ This line of reasoning - the reciprocal nature of the problem; the least cost solution - is found in Coase (1960).

${ }^{15}$ See Allen (1990) for an elaboration of this argument.

${ }^{16}$ Canada's 1968 divorce law was based on the recommendations of a special joint committee of Parliament. That report explicitly recognized the existence of inefficient marriages and the effect the switch to no-fault would have.
}

It is inevitable that when the grounds for divorce are widened, the divorce rate will increase to some degree. Initially, it can be expected to advance for a few years as the number of broken marriages that have been without relief heretofore are dissolved. ... The mere increase in the number of divorces granted, however, should not necessarily be a cause for alarm. The number means little if it merely reflects the regularization of what previously have been illicit unions. It is better for society that the divorce rate be higher, if the number of "common law" or bigamous unions be thereby reduced. (Debates, 1967, p.95) 
the probability of divorce because large positive or negative shocks can reverse the gains from being married to each other compared to being single or married to some one else. ${ }^{17}$

No-fault divorce became more valuable after 1970 in part because of a significant change in the degree and type of work by women after the second World War. Female work force participation had increased, and following Becker this lowered the gains from marriage. But what has also happened is some women moved into careers where their work patterns were identical to men. For these women the institutional benefits provided by marriage may be slight, especially where children are absent, and if children are present, where market services for nurturing the children are heavily employed.

The question arises, however, why would women who face only slight institutional benefits marry, or at least, marry under normal circumstances? And, in fact, if information costs regarding the identity of these women were low enough, marriage to and by them might be avoided. ${ }^{18}$ However, at the typical age of marriage for women, it may be too difficult to identify which ones will remain career-oriented and which others will leave the work force (at least part time) and engage in household production. The high 'variance' in female work patterns makes it difficult to identify these women at marrying age (perhaps even among themselves), and as a result more of these women marry and find themselves ending up in inefficient marriages. Hence, as the number of women in the work force increases, the probability of inefficient marriages increases because more marriages arise where the expected gains are low and more marriages arise where mistakes in partner selection is made. Both lead to an increase in the demand for divorce reform.

\subsection{Changes in the female work force}

The increase in female work force participation over the last century has been well documented and hardly needs detailed reporting here. Suffice to note that female participation in the work force has been common since the early 1800 s, and that in the last half of this century female participation has grown rapidly, with about half of the women ages 16 and over now holding paying jobs. Regarding the growth in participation rates Goldin (1990) says:

although increases in married women's participation are discernible in the 1920's among young women, the increases are most striking from the 1950's to the present. (p. 4)

Jacob (1988) also notes:

During the first half of the century, most married women stayed at home; in 1900, only $5.6 \%$ of those married worked outside the home; by 1940 that had risen only to

\footnotetext{
${ }^{17}$ If a couple does marry and it turns out that the marriage was a mistake, why should the couple divorce rather than renegotiate the marriage contract? Allen (1992a) notes that the inability to make side payments in a marriage share contract reduces the attractiveness of renegotiation, and makes marriages more vulnerable to unexpected shocks.

${ }^{18}$ By this I mean that the standard social contract we call 'marriage' might be avoided for a more specialized 'designer' contract.
} 
13.8\%. Thereafter, however, labor market participation of married women exploded with a rise of ten percentage points every decade. By 1985, 54.3\% of all married women were in the labor force. (pp. 17-18)

Finally, Fuchs (1988) states that "the most persistent change in gender roles since the end of World War II has been the surge of women into paid employment." (p. 11)

Not only has the incidence of working women increased, but the number of fields in which women work has increased as well:

...women entered a much larger range of occupations by the 1980 s than they had at the beginning of the century. Women became fire fighters, police officers, truckers, plumbers, and carpenters as well as lawyers, judges, doctors, and scientists. (Jacob, 1988, p. 18)

As was mentioned, this change in work force behavior was caused by a number of factors: changes in the nature of jobs, in education, in birth control, in working hours, and in household production technology, but regardless of the cause, increased female work force participation led to an increase in the number of inefficient marriages by increasing the probability of an error in estimating many wives' potential productivity in marriage. 19

The problem of estimation by husbands is compounded by the fact that work patterns are much more heterogeneous among women than men. Almost half of the married women are not in the work force. Of those women in the work force, they are more likely to work part-time and less likely to work over-time than are men. ${ }^{20}$ And yet there are many women that have work patterns identical to men. Work patterns for women are more sensitive to the number of children in a marriage, and women are still more likely to forsake job market activity when children require parental supervision (e.g. when sick), given current social norms. ${ }^{21}$ And yet there are women who do not behave this way. This is to say that the variance in the type of marital contribution of women as wives has increased over the last 50 years. Fifty years ago, there were not only fewer women in the work force, but the type of work and duration of participation was also much more restricted.

There is a larger variance in expectations as well. Ganong and Coleman (1992) found that among male and female college students a significant percentage still expected the husband to be more successful in any future marriage

...young adult males and females do not differ on expectations for personal success.... They do not, however, have similar expectations for the success of their future marital partners. Generally, young women expect more success for their future husbands than young men do for their future wives. Both males and females expect husbands to earn more, but males predict a larger difference in spousal incomes than do females. (pp. 60-61)

\footnotetext{
${ }^{19}$ Marital productivity is defined as the utility of contributions made to the marriage over the life cycle. These contributions can be in terms of income, children, or any service or good jointly valued by the couple.

${ }^{20}$ See, for example, Fuchs (1988), for statistical differences in the working patterns of men and women.

21 “... .many different kinds of evidence suggest that on average women feel a stronger desire for children than men do and a greater concern for their welfare after they are born." (Fuchs, 1988, p.4)
} 
Further, they note that

...nearly half the sample perceived that their partner would be similar to them in intelligence, ability, success, education, and income. A sizable percentage of the males could be said to have egalitarian expectations. (pp. 62-62)

The changes in work force behavior among women have taken place in a context where large numbers of people still hold traditional views on the roles of women, and where just as large numbers hold more progressive views. To the extent these expectations are not communicated accurately or do not remain constant, they create problems in estimating the value of future productivity within marriage. ${ }^{22}$

Hence, when a man is assessing the marital contribution of a woman, he is more likely to make a mistake than in the past, since larger variances in expectations and actual work behavior increase the noise in estimation. Goldin (1990), although in the context of an employer, makes this same observation:

Before 1940 , more than $80 \%$ of all married women had exited the labor force at marriage, and the majority never returned to work. But among married women who did remain at work, a substantial fraction worked for much of their lifetime. Employers, however, may have been unable, ex ante, to discern who among the single women would remain employed and who would not. (p. 7)

On the other side of the marriage market, women have not experienced a large change in the problems of estimating the productivity of future husbands. Changes in male work force' participation over the past 50 years has been trivial compared to female changes, and most men continue to work full time. This does not, of course, say that the problem of divorce is the fault of working women. Husbands today may expect to have their wives work and to work at a certain income level, but the wife may unexpectedly opt to work in the home. Divorce is not as much about working at home or working outside the home as it is about unfulfilled expectations.

If the probability of a mistake in spousal selection has increased over the last 50 years, the costs of a mistake have increased as well. Both men and women can expect to live longer today than they could 50 years ago. This is bad news, however, if stuck in an inefficient marriage. For women, the costs of remaining in an inefficient marriage are even higher - and not just because they live longer. For social and medical reasons, women can now postpone having children much longer. First-born children to women over 40 is not common, but neither is it rare or as dangerous as half a century ago. Starting a second family is also quite common. Finally, mortality for the mother during childbirth, though at one time quite real, is now rare. All of these features raise the benefits of a second marriage, and hence raise the costs for a wife of an inefficient marriage.

To summarize then, marriages where the benefits of being married are low and where there is an unexpected shock, are more likely to end up as inefficient marriages.

\footnotetext{
22 The empirical work later on looks at marriages beginning prior to 1968. What would the expectations of the husband be of the labor force participation of his wife in these marriages? Most likely they were that the wife would not work, or if she did, that she would quit to start a family. The surprise in these marriages would have been from those women that remained in the work force. The empirical work confirms this.
} 
Marriages where both spouses have identical work patterns will tend to have fewer gains because similar opportunity costs reduce the gains from specialization in household and market production. I have argued that a major social change across Western culture has been the change in female work force participation. Due to increase in the variance of female work force participation over the past 50 years, more individuals mistakenly entered into marriages where the gains were low. That is, marriages where work patterns for both spouses are unexpectedly identical. This increased the number of inefficient marriages, and hence changed the demand for divorce reform. ${ }^{23}$

\section{Testing the hypothesis}

There have been many attempts to theoretically link divorce rates with female work force participation, although with mixed success. Wives who work have better opportunities outside of marriage (the so-called independence effect), wives that earn more than their husbands usurp the traditional marital roles and create stress (the relative income effect), and working wives tend to spend less time at home and in household production (the absence effect). The empirical success of these theories has been mixed and weak. ${ }^{24}$ This paper has argued that work force participation plays a more subtle role. It is not the work force participation per se, but the increase in the number of mistakes in marriage partner selection that results from changing female roles which leads to marital instability. A recent study on marital disruption by Greenstein (1990) found several results that are consistent with this hypothesis. Among other things he found:

Women with lower levels of premarital work experience were somewhat less likely to experience marital disruption. Women who averaged more than 50 weeks per year in the labor force [prior to marriage] were about half again as likely to experience marital disruption as were women with no premarital work experience.... Women

\footnotetext{
${ }^{23}$ It could be argued that causality runs the opposite way. That is, increased work force participation by women is an act to insure against a higher probability of divorce under no-fault. Once no-fault divorce is in place or if it is widely anticipated, this incentive is obviously present. However, it is clear that changes in work force behavior happened long before changes in the divorce law, and it seems implausible that changes in female labor force behavior in the 1950s was in anticipation of legal changes 20 years later. Changes in other insurance-like behavior (co-habitation, increased age at marriage) took place during the no-fault era, and it seems likely that the incentive to 'work to insure' occured at this time as well. Further, this explanation is less plausible considering women have traditionally earned less outside of marriage than inside. As Jacob (1988) states, the perceptions of "viable alternatives to economic security through marriage ... outstripped reality, because most women continued to earn too little to support themselves (or their children) well" (p.18). Finally, the most recent empirical work rejects this 'independence' hypothesis as being empirically relevant. Greenstein (1990) states that "there seems to be no conclusive evidence supporting the existence of an independence effect on marital stability" (p.674).

${ }^{24}$ See Greenstein (1990) for a discussion of the literature. To quote Spitze and South (1985):

In the post World War II United States, two major transitions in family structure have attracted public attention and concern. Married female employment, especially that of young mothers, has burgeoned, and the proportion of marriages expected to end in divorce approaches $50 \%$. These trends have been linked ..., but the processes underlying the linkage remain unclear. (p.307)
}

This paper provides a theoretical linkage. Were it the case that work force participation reduced the divorce rate, the model here would be refuted. 
who averaged 35-40 hours at work per week were almost four times as likely to experience a marital disruption as were women who averaged less than 20 hours per week... (p. 673)

The role of premarital work experience is important. Women with no premarital work experience or full time experience had lower probabilities of divorce. These extreme premarriage work force behaviors could provide more information about future intentions and productivities than part-time work, and assist in the ex ante decision over the choice of spouse. Hence fewer mistakes are made and the probability of divorce is lower. Also notable is that women with work patterns similar to men have higher divorce probabilities. Other sociologists have found similar evidence that is consistent with the notion that it is the effect of working on expectations that matter. Booth et al. (1984) conclude:

Changes in wife's employment status also contribute to marital instability. ... the economic roles of women continue to change far more rapidly than men's. [Emphasis added] (pp. 581-582)

For this paper, two formal tests are conducted of the above hypothesis. The first test examines the relationship of work force participation and divorce by exploiting the switch to no-fault divorce in Canada. This test uses a duration model on data from the 1984 Family History Survey. Second, ordinary least squares regressions are run on a panel of divorces from the Census of Canada to corroborate the results from the Family History Survey.

\subsection{No-fault divorce in Canada}

\subsubsection{Canada's legal background}

Canada switched to no-fault divorce in 1968, and although the timing was similar, the Canadian law differs in several key ways from its U.S. counterparts. ${ }^{25}$ The 1867 constitution made marriage and divorce a federal responsibility, while property distribution was left to the provinces. ${ }^{26}$ Hence, unlike the US, when no-fault divorce was introduced in Canada with the 1968 Divorce Act, every province became no-fault at

\footnotetext{
${ }^{25}$ From a reading of the Parliamentary debate on the 1968 Canadian divorce law, there was little opposition. After the introduction of the bill, the leader of the opposition stated:

Mr. Chairman, in just a few words I should like to indicate that we on this side of the chamber approve of reforming the divorce law, and look forward to receiving the bill ... (Report, 1968, p.5017)

In the debate that follows, little is stated as to why the law should be changed. Members of Parliament repeatedly state that adultery and separation are not the only factors that could terminate the marriage, but fail to mention what other factors created inefficient marriages. An exception to this was the following exaggerated statement.

Today, heads of families are often forced to work far from home, in large as well as small towns. Moreover, the wives leave to seek outside work in order to make ends meet. Quite often, the husband and wife do not work the same hours; one works in the daytime, another at night, and sometimes vice versa. This means that sometimes they do not see each other for weeks.(Debates, 1967)

${ }^{26}$ In the U.S. these all fall under state jurisdiction.
} 


\section{Divorce Rate per 100,000 \\ Canada, $1922-1990$}

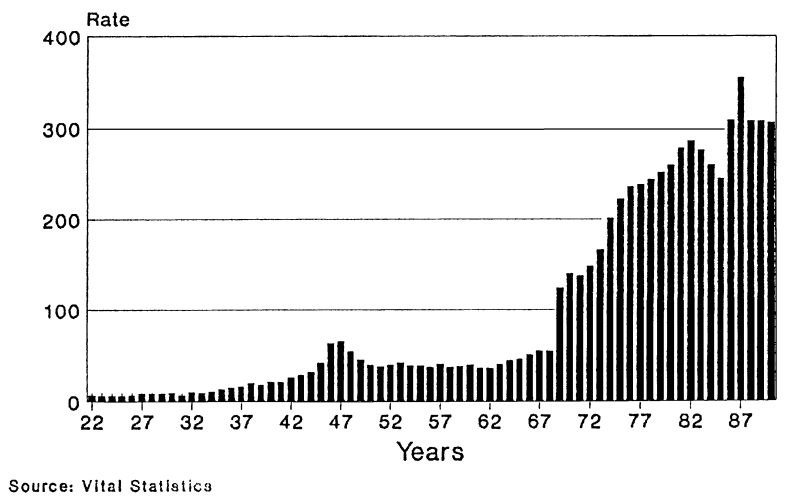

Fig. 1. Divorce rate per 100,000 in Canada: 1922-1990.

the same time. Furthermore, the concept of fault was removed from property division as well as the grounds for divorce.

Prior to 1968, the Federal government allowed individual provinces to legislate grounds for divorce. Eight provinces basically legislated adultery as the only grounds for divorce while Quebec and Newfoundland required a private act of Parliament's Senate to dissolve a marriage. The 1968 Divorce Act was the first unified set of rules on divorce in Canada, and established 15 different grounds for divorce. Most of these grounds were fundamentally fault grounds, but the list also included marital breakdown. ${ }^{27}$ The Divorce Act did not create a 'pure' no-fault law in that in the case of marital breakdown a divorce was not granted for 5 years for the deserting party, while the deserted could receive a divorce after 3 years. Given this long length of time the Canadian law was quite modest compared to some of the no-fault laws in the United States. Nevertheless, Fig. 1 shows a significant change in the divorce rate after 1968.

Although the grounds for divorce have been unilaterally decided by the federal government, each province legislates its own property division laws. All provinces but Quebec have a common law tradition, in which property was considered separate and title determined ownership. Under fault divorce this posed few problems; however, distributing property on the basis of title under no-fault can lead to involuntary transfers of wealth, because title does not always reflect the relative spousal contributions. Although this eventually led to legislative reforms regarding marital property around $1978-80,{ }^{28}$ the courts generally had some latitude to redistribute marital assets away from pure title distribution if it was felt warranted. Hence, during the first decade of no-fault some women may have been in jeopardy if the marital assets were mostly in the

\footnotetext{
27 According to Kronby (1991, p.xiv) "the grounds of adultery, cruelty and separation [marital breakdown] probably covered ninety-nine percent of the cases that came to court."

${ }^{28}$ See Knetsch (1984) for a discussion of the evolution of Canadian matrimonial property rules.
} 
husband's name. Although many inefficient divorces occurred, the relatively long length of time required for separation no-doubt insulated many Canadian women from inefficient divorces compared to their counterparts in the US. ${ }^{29}$

A second major change occurred in Canadian divorce law with the 1985 Divorce Act which became law in June 1986. The grounds for divorce were reduced from 15 to one (marital breakdown), which could be claimed by either partner and established by either living separately and apart for 1 year, adultery or cruelty. From an economic point of view the essential change in the new divorce law is that the length of separation was reduced to 1 year. However, given that the law was already no-fault, and that all provinces in the late 1970s and early 1980s had made some changes in their property laws to account for nonfinancial contributions and other non-market assets, this change, although making divorce easier, should not have had the same impact on the number of inefficient divorces as the 1968 change.

\subsection{Empirical results: Family History Survey}

Fig. 1 showed a change in the divorce rate coinciding with the introduction in 1968 of no-fault divorce. This change in the divorce rate is similar to the American experience, and the standard question is, did the change in law cause the change in divorce rate? The usual procedure in cross-state studies is to include a no-fault dummy variable for the occurrence of no-fault, holding a number of demographical features constant. This procedure, however, may be incorrect. Starting with the conjecture that no-fault divorce does make divorce easier ${ }^{30}$ and maintaining that inefficient marriages did exist at the time the law switched, then there will occur two types of divorces: efficient divorces, where spouses correct earlier mistakes in selection; and inefficient divorces, where one spouse takes advantage of the new law and exploits the poor bargaining position of the other. If the probability of an inefficient marriage is correlated with the demographic variables in the regression, then the no-fault dummy will pick up only the inefficient divorces - not all divorces. Hence the no-fault law might increase the divorce rate through an increase in efficient divorces, but a researcher may still conclude that the law had no impact on divorce.

For example, and in order to facilitate the interpretation of the results presented later, consider the following stylized regression:

$$
\text { divorce }=\alpha+\beta_{1} * D_{\mathrm{i}}+\beta_{2} * D_{\mathrm{nf}}
$$

where divorce is a dummy variable that equals 1 if divorced, $D_{\mathrm{i}}$ is a dummy variable that equals one if a marriage ends up being inefficient, and $D_{\mathrm{nf}}$ is a dummy variable that

\footnotetext{
${ }^{29}$ The most famous case in Canada is Murdoch $v$ Murdoch (1975, 1 SCR 423; 1974, 41 PLR (3 ${ }^{\mathrm{d}}$ ) 367). Here a couple farmed in Alberta for 25 years, during which time Mrs. Murdoch made significant contributions to the farm. However, since she made no financial contribution and property was held by her husband, she walked away with basically the dress on her back. In Canada it is a stylized fact that after this case the lobbies for property distribution reform gained momentum, and that the courts took more liberty in awarding property to wives.

${ }^{30}$ This is held throughout the paper. If there are costs of reaching an agreement, then no-fault must lower the cost of divorce, since it eliminates the need for agreement.
} 
Table 1

Efficient and Inefficient Divorce Possibilities

\begin{tabular}{llll}
\hline Divorce & $D_{\mathrm{i}}$ & $D_{\mathrm{nf}}$ & \\
\hline 1 & 1 & 1 & Efficient divorce \\
1 & 0 & 1 & Inefficient divorce \\
1 & 1 & 0 & Efficient divorce \\
1 & 0 & 0 & Inefficient divorce \\
\hline
\end{tabular}

equals one when there is no-fault divorce. From the model of divorce discussed above there are several divorce possibilities of interest, and they are shown in Table 1.

The first row represents an efficient divorce since a marital mistake has been made, while the second row is an inefficient divorce - both when the law is no-fault. As argued above, both of these are quite possible. The third and fourth rows represent another pair of efficient and inefficient divorces under fault law. Given the mutual nature of fault law, however, the last of these divorces is quite improbable. If the assumption that no-fault makes divorce easier is maintained, then most of the observed divorces should be under the no-fault law. If an interaction term, $\beta_{3} * D_{\mathrm{i}} D_{\mathrm{nf}}$, is introduced into the regression, then $\beta_{3}$ will capture the efficient divorces under the no-fault law since $D_{\mathrm{i}} D_{\text {nf }}$ equals one only when the law is no-fault and a mistake has been made. Including this term, however, also implies that $\beta_{2}$ measures the impact of inefficient divorces under no-fault, while $\beta_{1}$ measures the impact of efficient divorces under the fault law. In practice, of course, the mistake variables are just proxies; however, the interpretation remains the same: the law dummy variables capture inefficient divorces, while the interactive variables reflect efficient divorces.

The main hypothesis of this paper is that the switch to no-fault divorce was the result of pressure from inefficient marriages. Therefore the interactive variables are predicted to be significant. The second contribution of this paper is to estimate for the first time for Canada, a sign for the coefficients for the inefficient divorces - the law dummy variable. Given the U.S. experience and the known presence of transaction costs with marriages, the law dummy variable is expected to be positive, but their magnitude and variance will depend on many factors, including the property division laws at the time of the no-fault switch. In Canada, the title-based property division laws and the removal of fault in consideration of property settlements increased the likelihood of inefficient divorces, while the long length of separation required for divorce would tend to reduce it. Hence the no-fault law variable is expected to have a positive impact on the divorce rate, but the magnitude and level of significance is an empirical matter.

Data for the regression on divorce come from the 1984 Family History Survey (FHS) which supplemented the 1984 Labour Force Survey and was conducted by Statistics Canada. The data are retrospective, and so a history or time series, of some variables is possible to construct for each individual. Women were selected for the sample if they were the head or spouse of the head of household, if they had been married only once, and 
Table 2

Definition of variables

\begin{tabular}{|c|c|}
\hline \multicolumn{2}{|l|}{ Dependent variable } \\
\hline LENGTH & The length of marriage as of 1984 \\
\hline \multicolumn{2}{|c|}{ Independent variables } \\
\hline L-PART & Average labor force participation over the life of marriage \\
\hline L-VARIANCE & Variance in labor force participation over the life of marriage \\
\hline YOUNG & 1 if woman married before she was 19 \\
\hline NOFAULT & 1 from 1968 to 1984 , the period of nofault divorce in Canada \\
\hline CHILDREN & Total number of children as of 1984 \\
\hline CHILD SQ & CHILREN $\times$ CHILDREN \\
\hline COMLAW-DIV & 1 if respondent had ever lived with someone other than spouse \\
\hline COMLAW-MAR & 1 if respondent had lived common law with spouse \\
\hline \multirow[t]{5}{*}{ EDUCATION $^{\mathrm{a}}$} & 0 if respondent had no schooling \\
\hline & 1 if respondent had $1-8$ years of schooling \\
\hline & 2 if respondent had $9-10$ years of schooling \\
\hline & 3 if respondent had 11 years of schooling \\
\hline & 8 if respondent had undergraduate degree \\
\hline EDUC SQ & EDUCATION $\times$ EDUCATION \\
\hline YOUNG-NF & YOUNG $\times$ NOFAULT \\
\hline L-VAR-NF & L-VARIANCE $\times$ NOFAULT \\
\hline L-PART-NF & L-PART $\times$ NOFAULT \\
\hline
\end{tabular}

${ }^{a}$ The non-linear EDUCATION variable is as it is coded in the data.

Table 3

Descriptive statistics

\begin{tabular}{|c|c|c|}
\hline Name & Mean & SD \\
\hline \multicolumn{3}{|l|}{ Dependent variable } \\
\hline LENGTH & 19.02 & 11.98 \\
\hline \multicolumn{3}{|c|}{ Independent variables } \\
\hline L-PART & 0.31 & 0.28 \\
\hline L-VARIANCE & 0.13 & 0.09 \\
\hline YOUNG & 0.15 & 0.36 \\
\hline CHILDREN & 2.59 & 1.93 \\
\hline CHILD SQ & 10.46 & 17.40 \\
\hline COMLAW-DIV & 0.02 & 0.13 \\
\hline COMLAW-MAR & 0.07 & 0.25 \\
\hline EDUCATION & 3.87 & 2.31 \\
\hline EDUC SQ & 20.39 & 20.51 \\
\hline Sample Size & 2690 & \\
\hline \multicolumn{3}{|l|}{ Percent censored } \\
\hline (Married) & 0.924 & \\
\hline
\end{tabular}

The interaction terms are created internally by BMDP, since they are time-varying covariates. Hence no summary statistics are created for them. 
Table 4

Partial likelihood estimates

\begin{tabular}{|c|c|}
\hline CHILD & $\begin{array}{l}-.408 \\
(-6.54)^{\mathrm{a}}\end{array}$ \\
\hline CHILD SQ & $\begin{array}{l}0.34 \\
(5.85)^{*}\end{array}$ \\
\hline L-VARIANCE & $\begin{array}{l}6.29 \\
(1.93)^{*}\end{array}$ \\
\hline L-PART & $\begin{array}{l}-1.40 \\
(-1.27)\end{array}$ \\
\hline COMLAW-DIV & $\begin{array}{l}2.64 \\
(15.18)^{*}\end{array}$ \\
\hline COMLAW-MAR & $\begin{array}{l}.726 \\
(3.24)^{*}\end{array}$ \\
\hline EDUCATION & $\begin{array}{l}.123 \\
(1.11)\end{array}$ \\
\hline EDUC SQ & $\begin{array}{l}-.012 \\
(-.99)\end{array}$ \\
\hline YOUNG & $\begin{array}{l}.657 \\
(4.90)^{*}\end{array}$ \\
\hline YOUNG-NF & $\begin{array}{l}1.34 \\
(3.04)^{*}\end{array}$ \\
\hline L-VAR-NF & $\begin{array}{l}-5.81 \\
\left(-1.75^{*}\right.\end{array}$ \\
\hline L-PART-NF & $\begin{array}{l}2.02 \\
(1.81)^{*}\end{array}$ \\
\hline NOFAULT & $\begin{array}{l}1.09 \\
(2.86)^{*}\end{array}$ \\
\hline Log Likelihood & -2605 \\
\hline
\end{tabular}

Asymptotic $t$-statistics in parentheses.

${ }^{\text {a }}$ Significant at $10 \%$

if they were married prior to 1968 . Table 2 presents the variables used, while Table 3 provides some descriptive statistics. ${ }^{31}$

Due to the retrospective nature of the data, information on the beginning dates, as well as some ending dates of marriages is available.

A duration model provides the appropriate statistical method to analyze the effect of various covariates on the probability that a marriage will end in divorce, given that it has lasted a certain length of time. ${ }^{32}$ Such models, when estimating the probability of a divorce, take into account the duration of the marriage. The class of model used here is a proportional hazard specification of the form:

$$
\lambda\left(t, X, \beta, \lambda_{0}\right)=e^{X^{\prime} \beta} \lambda_{0}(t)
$$

\footnotetext{
${ }^{31}$ L-PART and L-VARIANCE, the average and variance of labor force participation over the life of the marriage, may require further explanation. The data contain a history of each respondent's entries and exits from the labor market. For any given year, 1 is assigned if the respondent is working, and a zero if not. L-PART is simply the average of these dummy variables, while L-VARIANCE is their variance.

${ }^{32}$ See Kiefer (1988) for a detailed discussion of Hazard models.
} 
where $t$ is duration time, $X$ is a set of explanatory variables with unknown coefficients $\beta$, and $\lambda_{0}$ is a baseline hazard. This model has two nice features. First,

$$
\frac{\partial \ln \lambda}{\partial x}=\beta
$$

and "so the coefficient can be interpreted as the constant proportional effect of $x$ on the conditional probability of completing a spell.," 33 Or, in terms of the marriage model here, where 'completion' refers to the marriage ending in divorce, $\beta$ measures the impact of $x$ on the conditional probability of becoming divorced. Second, the model can be estimated using a partial likelihood approach that allows for time-varying covariates and estimation of $\beta$ without estimating the base-line hazard. Table 4 presents the partial likelihood estimates. ${ }^{34}$ The coefficients then, are interpreted as follows: for the NOFAULT variable, $\beta=1.09$ simply means that a movement to the nofault period increased the probability of divorce, conditional on the length of marriage by 1.09 percent. This result is statistically significant, and is consistent with the recent U.S. findings that no-fault divorce increases the divorce rate.

The results of Table 4 confirm some well-known relationships with divorce, in addition to testing the hypothesis of this paper. First, as might be expected, the presence of children reduces the probability of divorce, but with large numbers becoming destabilizing. Individuals that live common law before marriage, even when they end up marrying their common-law spouse, increase the probability of divorce. ${ }^{35}$

\footnotetext{
${ }^{33}$ Kiefer (1988), p.664.

${ }^{34}$ With the proportional hazard model there is a positive probability that the likelihood function becomes monotone when covariates have extreme effects. For example, suppose there are two groups of patients: one receives treatment, while the other does not. Suppose that everyone receiving treatment lives, while everyone else dies. The proportional hazards model cannot estimate the effect of treatment on survival. Under such circumstances "the partial likelihood will be monotone in $\beta$, leading to the estimate $\hat{\beta}=\infty$ or $\hat{\beta}=-\infty$." (see Bryson and Johnson, 1981, p.381 for a discussion of the problem). When multiple covariates, and especially time-varying covariates, are used the problem is enhanced and the extreme effect needs only to be approximate. Unfortunately this problem exists in the survey data used here. Most of the divorces take place after 1968 (184 out of 205, or $89.7 \%$ ), and so the estimate on the NOFAULT dummy is infinite. Stratifying the sample by NOFAULT was impossible since the computer software creates this variable internally, and so the ultimate solution used was to actually start the NOFAULT dummy in 1970. What this does is count some of the divorces (21, in fact) as occurring during a fault period, and biases the result downward against the hypothesis of the paper.

It is possible to modify the sample in a way which allows a logit regression. Although not the appropriate econometric technique, the logit model does not fail with the presence of extreme effects. The results are similar, and in particualar, the signs and significance levels of the troublesome NOFAULT variable remain unchanged. This regression and procedure are not reported, but are available from the author.

35 This is a fascinating result, and worthy of further study. My speculation is that a failed common-law relationship is similar to a past divorce. As is well known, the probability of divorce is higher given a previous divorce. As for those that marry their common-law spouse, delaying marriage may reflect low gains from marriage. Therefore, the higher probability of divorce reflects the fact that these were marginal marriages to begin with. It should be pointed out that this finding is not unique. Booth and Johnson (1988) find a similar result.
}

On the basis of an examination of the relationship between cohabitation and marital quality with a national sample of married persons, ... [t] $]$ here is a modest but consistent relationship between cohabitation and lower marital interaction, elevated disagreement, divorce proneness, and divorce and permanent separation among nonminorities. (p.270) 
The three variables used to proxy mistakes are YOUNG, L-PART, and L-VARIANCE. The YOUNG variable is one when the wife married prior to 19 years of age. The result, as found elsewhere, is that marrying young increases the probability of divorce. Of more concern here are the average labor force participation, and the variance in that participation which are the variables that were suggested to be important. If we look at the interaction terms that capture efficient divorces, we see that women who entered the work force and stayed there - that is, women that had high labor force participation and low variances in that participation - were the ones that divorced under no-fault. This result confirms the prediction by Becker, et al. that in marriages where there are low gains to marriage (due to a lack of specialization in this case) the probability of divorce is higher. The twist added by this paper is that these professional or full-time working women are particularly difficult to identify at the age of marriage, and so more of them get married than would have, had information of their future work patterns been better. This problem would have been exacerbated during the 1950s and 1960s when most men (and probably women) did not expect some female work patterns to mimic men's. Hence the result here suggests that there was a significant increase in efficient divorces after the introduction of no-fault. ${ }^{36}$

The NOFAULT variable, which captures the inefficient divorces, is also positive. In most of the papers on divorce this would be used to conclude that the switch in law did increase the divorce rate. The argument here is that such a conclusion is incomplete. The variable indicates that a particular type of divorce increased, namely, inefficient divorces, where one spouse used the new law to the disadvantage of his or her partner. As stated above, this variable fails to capture the efficient divorces. This final result suggests that in Canada, in addition to efficient divorces, there was a significant number of inefficient ones involving illegitimate wealth transfers as well.

\subsection{Empirical results: Vital statistics}

This section of the paper briefly presents some additional evidence from the vital statistics of Canada to corroborate some of the results from the last section. Using the Census of Canada (various issues) a panel of divorces in Canada from 1950 to 1992 is created. This panel includes every divorce in the country over this period. Using dummy variables for the law, provinces, and a time trend, allows for regional and inter-temporal effects to be captured in an ordinary least squares regression. Under such a specification the dummy variables for the change in legal regime once again capture the inefficient divorce effect. The interactive variables summarize all inter-provincial differences, however, and do not isolate or proxy incidences of mistakes. Therefore, their coefficients cannot be interpreted in terms of efficient divorces.

\footnotetext{
${ }^{36}$ A likelihood ratio test was performed on the set of the three mistake variables. The LR was equal to 14.44, which is larger than the $\chi^{2}$ critical value of 7.81 with three degrees of freedom.
} 
Table 5

Census regressions on no-fault divorce

\begin{tabular}{|c|c|c|c|}
\hline Variable & I & II & III \\
\hline NOFAULT $^{68}$ & $149.5(21.76)^{\mathrm{a}}$ & $149.5(33.51)^{*}$ & $70.2(6.87)^{*}$ \\
\hline NOFAULT $^{85}$ & $76.7(8.30)^{*}$ & $76.7(12.78)^{*}$ & $36.5(6.43)^{*}$ \\
\hline $\mathrm{BC}$ & & $164.7(18.07)^{*}$ & $81.6(5.90)^{*}$ \\
\hline ALTA & & $157.1(17.24)^{*}$ & $18.6(1.34)$ \\
\hline SASK & & $54.8(6.01)^{*}$ & $-6.6(-.48)$ \\
\hline MAN & & $8.4(.65)$ & $11.3(.82)$ \\
\hline ONT & & $104.2(11.43)^{*}$ & $20.9(1.51)$ \\
\hline QUE & & $75.1(8.24)^{*}$ & $-47.5(-3.43)^{*}$ \\
\hline NB & & $5497(6.02)^{*}$ & $-14.6(-1.05)$ \\
\hline NS & & $87.4(9.59)^{*}$ & $-19.6(-1.42)$ \\
\hline PEI & & $23.2(2.55)^{*}$ & $-26.5(-1.91)^{*}$ \\
\hline $\begin{array}{l}\text { Adjusted } R^{2} \\
\text { TIME"PROV }\end{array}$ & .65 & .91 & .92 \\
\hline $\begin{array}{l}\text { Included } \\
\text { NOFAULT }^{68 *} \text { PROV }\end{array}$ & NO & NO & YES \\
\hline $\begin{array}{l}\text { Included } \\
\text { NOFAULT }^{85 *} \text { PROV }\end{array}$ & No & NO & YES \\
\hline Included & No & NO & YES \\
\hline $\mathrm{N}$ & 430 & 430 & 430 \\
\hline $\mathrm{F}$ & 404.4 & 228.4 & 137.0 \\
\hline
\end{tabular}

Dependent variable $=$ Divorces per 100,000.

$t$-statistics in parentheses.

${ }^{\text {a }}$ Significant at $10 \%$ level.

Source: Census of Canada, various years.

Interactive terms are not reported for the third regression, but are available from the author.

The regressions reported in Table 5 are all of the form:

$$
\begin{aligned}
\text { DIV }- \text { RATE}_{p t}= & \alpha+\beta_{1} \text { NOFAULT }_{t}^{68}+\beta_{2} \text { NOFAULT }_{t}^{85}+\beta_{3} \text { PROV }_{p} \\
& +\beta_{4} \text { TIME }_{t} * \operatorname{PROV}_{p}+\beta_{5} \text { NOFAULT }_{t}^{68} * \operatorname{PROV}_{p} \\
& +\beta_{6} \text { NOFAULT }_{t}^{85} * \operatorname{PROV}_{p}+\epsilon_{p t} .
\end{aligned}
$$

where the subscript $p$ indicates province, and the subscript $t$ indicates year. Hence, the dependent variable is the divorce rate, and is the number of divorces per 100,000 people in each province for a given year. NOFAULT ${ }^{68}$ and NOFAULT ${ }^{85}$ are dummy variables for the 1968 and 1985 law changes. The variable TIME is a time trend, while PROV is a vector of dummy variables for each province. ${ }^{37}$ The variable PROV captures different regional effects, and the interactive term allows for provincial trends in characteristics that may be correlated with the divorce rate.

Table 5 reports various regressions, introducing more control variables moving from the left to the right of the table. Regressions I and II include only the variables reported in the table. Regression III, however, includes the following vectors of interactive terms: TIME*PROV, NOFAULT ${ }^{68 *}$ PROV, and NOFAULT ${ }^{85} *$ PROV. In the interests of space

\footnotetext{
${ }^{37}$ In the regressions, Newfoundland is the omitted province.
} 
these results are not shown, but are available from the author. In all the regressions the coefficients for NOFAULT ${ }^{68}$ and NOFAULT ${ }^{85}$ are significant and positive. As with the Family History Survey, this indicates that both changes in divorce law increased the number of inefficient divorces. This holds even when provincial effects and intertemporal provincial effects are controlled for.

\section{Conclusion}

What is at fault for no-fault, and what was its effect? I have argued that the change in law was motivated by a rise in the number of inefficient marriages throughout the 1950s and 1960s, which resulted in part from changes in the work patterns of women that were unanticipated by men. These were marriages in which the partners erred in estimating the future contributions of their spouse, but in which transaction costs prevented a divorce from occurring. Under no-fault divorce, the cost of obtaining a divorce falls, and what were previously inefficient marriages become efficient divorces. For different transaction cost reasons some efficient marriages also end in divorce under the no-fault law.

Looking back at Fig. 1, the analysis here can provide a crude explanation for why the divorce rate jumped up in 1968, rose and then began to gradually fall, and then jumped up again in 1985. The jump in 1968 has been dealt with, and the rise over the next several years resulted from the 5-year separation requirement. That is, the initial increase in divorces was made by people that were separated prior to the change in the law. In 1968 those that had been separated for at least 5-years could divorce, in 1969 those that had been separated for 4 years in 1968 divorced, and so on. However, the gradual fall is probably the result of a fall in inefficient divorces. As the new law becomes known, individuals make adjustments in factors such as searching for spouses, age at marriage, delineation of assets, and pre-nuptial agreements that reduce the probability of an inefficient divorce. The divorce rate does not fall to the 1968 level because there has been a permanent increase in difficulty to identify women who will have work patterns that make the gains to marriage low, and so there will be a larger number of efficient divorces than prior to 1968. In fact, the higher steady-state divorce rate that exists almost 25 years after the legal change, is perhaps the strongest evidence for the existence of efficient divorces. The jump in 1985 was the result of lowering the separation time to 1 year, which mimics, to a smaller degree, all of the 1968 effects. Ceteris paribus, the argument presented here would predict a fall in the divorce rate over time from 1985, to a level that is still higher than the pre-1968 level.

To summarize the key empirical findings, the no-fault law variables were statistically different from zero and positive. This held true for the results from the Family History Survey and from a panel created from Vital Statistics. However, the paper also provided some evidence that the law had a more subtle impact. The interaction between the nofault dummy and the mistake variables in Table 4 indicates that the switch in law induced efficient divorces as well as inefficient ones. This distinction between the two types of divorces may explain the paradox that while casual observation suggests that the switch in law mattered, some early empirical tests had claimed that it did not. In any event, a perhaps more important underlying theme to this paper, and one that could be exploited in 
subsequent work, is that the switch to no-fault divorce was no accident, but was rather the response to economic forces.

\section{Acknowledgements}

Although I am grateful to Yoram Barzel, Margaret Brinig, John Chant, Richard Epstein, Jane Freisen, Larry Iannaccone, Mark Kamstra, Peter Kennedy, Dean Lueck, Sam Peltzman, Zane Spindler, Rolf Weder, Martin Zelder, and seminar participants at the Universities of Quebec at Montreal, Toronto, and British Columbia for their comments, none are at fault for any of the paper's shortcomings.

\section{References}

Allen, Douglas, 1990. An inquiry into the state's role in marriage. Journal of Economic Behavior and Organization 13(2), 171-191.

Allen, Douglas, 1991. What are transaction costs? Research in Law and Economics, 14, Fall, 1-18.

Allen, Douglas, 1992a. What does she see in him?: The effect of sharing on the choice of spouse, Economic Inquiry, January, pp. 57-67.

Allen, Douglas, 1992b. Marriage and divorce: Comment, American Economic Review, June, 679-685.

Becker, Gary, Landes, Elizabeth, Michael, Robert, 1977. An economic analysis of marital instability. Journal of Political Economy 85, 1141-1187.

Booth, Alan, Johnson, David, 1988. Premarital cohabitation and marital success. Journal of Family Issues 9 , June, 255-272.

Booth, Alan, Johnson, David, White, Lynn, Edwards, John, 1984. Women, outside employment, and marital instability. American Journal of Sociology 90, 567-583.

Bryson, Maurice, Johnson, Mark, 1981. The incidence of monotone likelihood in the Cox model. Technometrics 23, 381-384.

Commons Debates, Queen's Printer, Ottawa, 1967.

Freed, D., Foster Jr., H., 1979. Divorce in the fifty states: An overview as of 1978. Family Law Quarterly 13, $105-128$.

Fuchs, Victor, 1983. How We Live, Harvard University Press, Cambridge, MA.

Fuchs, Victor, 1988. Women's Quest for Economic Equality, Harvard University Press, Cambridge, MA.

Ganong, Lawrence, Coleman, Marilyn, 1992. Gender differences in expectations of self and future partner, Journal of Family Issues, 13 March, 55-64.

Goldin, Claudia, 1990. Understanding the Gender Gap: An Economic History of American Women, Oxford University Press.

Greenstein, Theodore, 1990. Marital Disruption and the employment of married women, Journal of Marriage and the Family 52, August, 657-676.

Jacob, Herbert, 1988. Silent Revolution: The Transformation of Divorce Law In the United States, University of Chicago Press.

Kiefer, Nicholas, 1988. Economic duration data and hazard functions. Journal of Economic Literature 26, 646679.

Knetsch, Jack, 1984. Some economic implications of matrimonial property rules. University of Toronto Law Journal 34, 263-282.

Thomas, Marvell, 1989. Divorce rates and the fault requirement. Law and Society Review 23(4), 543-567.

Michael, Robert, 1978. The rise in divorce rates, 1960-1974: Age-specific Components. Demography 15, 3751.

Parkman, Allen, M., 1992a. No-Fault Divorce: What Went Wrong? Westview Press, Boulder, CO.

Parkman, Allen, 1992b. Remedies for breach of the marriage contract, mimeo, University of New Mexico. 
Peters, Elizabeth H., 1986. Marriage and divorce: Informational constraints and private contracting, American Economic Review, June, 437-454.

Peters, Elizatheth H., 1992. Marriage and divorce: Reply, American Economic Review June, 686-693.

Posner, Richard, 1992. Sex and Reason, Harvard University Press, Cambridge, MA.

Report of the Special Joint Committee of the Senate and House of Commons on Divorce, 1967, Queen's Printer, Ottawa, 1967.

Spitze, Glenna, South, Scott, September 1985. Women's employment, time expenditure, and divorce, Journal of Family Issues 6. 307-330.

Wittman, Donald, 1989. Why democracies produce efficient results. Journal of Political Economy 97, 13951424.

Zelder, Martin, 1992. Did no-fault divorce law increase the divorce rate? A critical review of the evidence, mimeo. Northwestern Law School.

Coase, R., 1960. The Problem of social cost. Journal of Law and Economics 3, 1-44. 